\title{
内陸の地方都市における都市気候の実態に関する研究 A STUDY ON THE ACTUAL CONDITIONS OF THE URBAN CLIMATE IN THE INLAND PROVINCIAL CITIES
}

\author{
岩井一博*1, 高木直樹*2, 三谷弘眞*3, 山下恭弘*4 \\ Kazuhiro IWAI, Naoki TAKAGI, Hiromasa MITANI \\ and Yasuhiro YAMASHITA
}

This paper describes measurement results about climate in 5 local inland cities, Nagano, Matsumoto, Maebashi, Gifu and Kofu. The measurements were done throughout the year at 5 different land use areas in 5 cities.

The results were shown as follows.

(1) The actual conditions of 5 cities about mean air temperature, maximum air temperature, minimum air temperature and absolute humidity mixing ratio were obtained. About mean air temperature at park area is lower than another areas, the differences were $1.1 \sim 2.5$ Celsius.

(2) About air temperature at commercial area and low-rise housing area, the comparison between 5 cities and metropolitan cities, Tokyo and Osaka, the differences of maximum air temperature, minimum air temperature and diurnal range become clear. Especially, in 5 local cities, air temperature at commercial area is low in daytime and high in nighttime.

(3) At maximum air temperature day and minimum air temperature day, absolute humidity mixing ratio at commercial area is lower than low-rise housing area.

Keywords: provincial city, urban climate, land use, fixed point measurement, Nagano City

地方都市，都市気候，土地利用，定点測定，長野市

1.はじめに

本研究者らは、建物の熱負荷シミュレーション計算や有効なパッシ ブ手法の検討を行うため、約 $20 \mathrm{~km}$ 四方の領域を対象とした気象観測 を行っている。特に長野市においては、土地利用や標高の違いによる

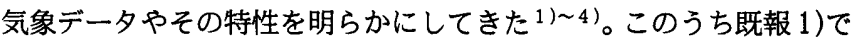
は、対象地域内の $20 \mathrm{~km}$ 四方において土地利用が等しい場合、気温と 相対湿度の值は信頼度 $95 \%$ でほぼ一致する結果が得られた。既報 2) では、長野市を対象に $500 \mathrm{~m} \times 500 \mathrm{~m}$ のメッシュ毎の気温と相対湿度の 実測データに基づく気象マップを作成した。既報 3)においては気象 項目を 7 項目に増やし、約 $30 \mathrm{~m} \times 30 \mathrm{~m}$ のメッシュによる気象マップを 作成した。既報 4)では、土地利用と標高の両者を考慮した長野市全 体の気象マップを作成した。

こうした一連の研究により、長野市では商業地域の気温が他の地域 に比べて日中は低く、夜間は高いなどの様々な気象の実態を明らかに
する事ができた。しかしながら、この様な気象特性が日本全体の内陸 の地方都市においても、同様の結果を示すかについては明らかになっ ていない。そのため、本論文では長野市と同様に、比較的狭い範囲に 多種多様な土地利用が存在し、人口と規模が同程度の内陸の地方都市 である、松本市、前橋市、岐卓市、甲府市を実測の対象地域とした。 その際、4都市の対象地域内において土地利用が異なる代表点をそれ それ選定し、長野市で行った方法に準拠して通年における気温と相対 湿度の連続測定を行うことにした。

よって本論文では、長野市を含めた 5 都市において気象観測を行い、 内陸の地方都市における都市気候の実態を明らかにする事を目的と する。この結果により、各都市の気候の共通点と特性を明らかにし、 それぞれの都市における建物の熱負荷シミュレーション計算と、有効 なパッシブ手法の検討のための資料を作成することを研究の最終目 標とする。

\footnotetext{
*1 信州大学工学部社会開発工学科 技術専門職員 ·博士 (工学)

*2 信州大学工学部社会開発工学科 助教授・工博

*3 信州大学大学院 大学院生

*4 信州大学工学部社会開発工学科 教授・工博
}

Engineer, Dept. of Arch. and Civil Engineering, Faculty of Engineering, Shinshu Univ., Dr. Eng.

Assoc. Prof., Dept. of Arch. and Civil Engineering, Faculty of Engineering, Shinshu Univ., Dr. Eng.

Graduate Student, Graduate School, Faculty of Engineering, Shinshu Univ. Prof., Dept. of Arch. and Civil Engineering, Faculty of Engineering, Shinshu Univ.,
Dr. Eng. 


\section{2. 既往の研究と本研究の位置づけ}

都市気候に関する既往の研究を整理する。

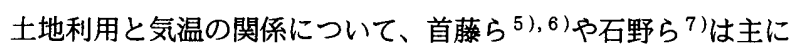
首都圏を中心に解析を行っている。気温分布と熱環境については、

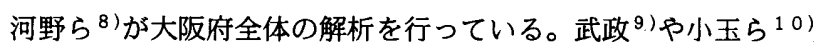
は建築設計用地域気候マップを作成し、冬期における日本全体の 気温や日射量の実態を明らかにしている。西川ら ${ }^{11}$ は、九州地 方を対象に気象デー夕の整備を行っている。無漏田ら ${ }^{12)}$ は、市 街地の緑地整備量と気候の関係について解析している。水域の都 市気候への影響については、片山ら ${ }^{13)}$ 、村川ら ${ }^{14)}$ 、成田ら ${ }^{15)}$ 、 向井ら ${ }^{16)}$ の報告がある。また、都市気候のモデリングに関して は、村上ら 17)の土地利用状況の変化と流れ場・温度場の関係、 ヴタンカら ${ }^{18)}$ の都市大気境界層の乱流モデリング、竹林ら ${ }^{19)}$ の観測データとの併用による気候解析、吉田 $\left.{ }^{20}\right)$ による近畿地方 の解析などがある。一方、リモートセンシング技術を利用した都 市気候の研究には、渡辺ら 21)や梅干野ら 22)による地表面温度の 分布についての報告がある。

この他、都市気候に関する多くの研究 23 )-30)が報告されてお り、こうした一連の研究により国内各地の都市における気象デー タやその特性が明らかになった。しかしながら、これらの研究は 首都圈や大都市を対象とした報告が主体となっている。従って、 地方都市を対象とした解析は不足しており、そのため外界気象の 計測とデー夕に基づく気象の解析が必要であると考える。

本論文は、この様な背景に基づいて内陸の地方都市を対象に都 市気候の実態を明らかにする。その手順として、初めに 5 都市の 対象地域内において何れも土地利用の異なる代表点を選定し、通 年における気温と絶対湿度の経時変化を明らかにしている。次に 最寒日と最暑日における気温と絶対湿度を大都市と比較し、これ らの結果をまとめて、内陸の地方都市における都市気候を明らか にしている。

\section{3. 対象地域及び測定方法}

本論文では、図ー 1 に示す 5 都市を研究の対象地域とした。何 れの都市も内陸に位置し、人口密度は約 2,100 人 $/ \mathrm{km}^{2}$ 〜 約 3,900 人 $/ \mathrm{km}^{2}$ の規模となっている。なお、それそれの対象地域は平地部 の標高差が 80m. 以内の範囲としている。標高に伴う気温減率を $0.6^{\circ} \mathrm{C} / 100 \mathrm{~m}$ とすると、この範囲での気温差は $0.5^{\circ} \mathrm{C}$ 以下であるた め、標高による影響は少ないと判断した。長野市を例に、研究の 対象地域を図ー 2 に示す。また、長野市における代表点の概要を 図一 3 に示す。各代表点俚図- 2 の対象地域の中から土地利用に 基づいて選定しており、それぞれ、公園地域、低層住宅地域、商 業地域、中層住宅地域、果樹農家地域と呼称する。各代表点では、 何れもの印の地面より $1.5 \mathrm{~m}$ の高さに温湿度計を設置し、10 分毎 の瞬時値を記録した。使用した測定器は、温度がサーミスタ式で、

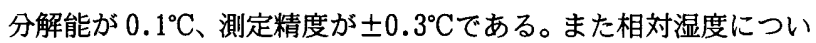
ては高分子型で、分解能が $1 \%$ 、測定精度が $\pm 5 \%$ ある。測定 点の選定方法は周囲の土地利用を代表する中央付近とし、測定器

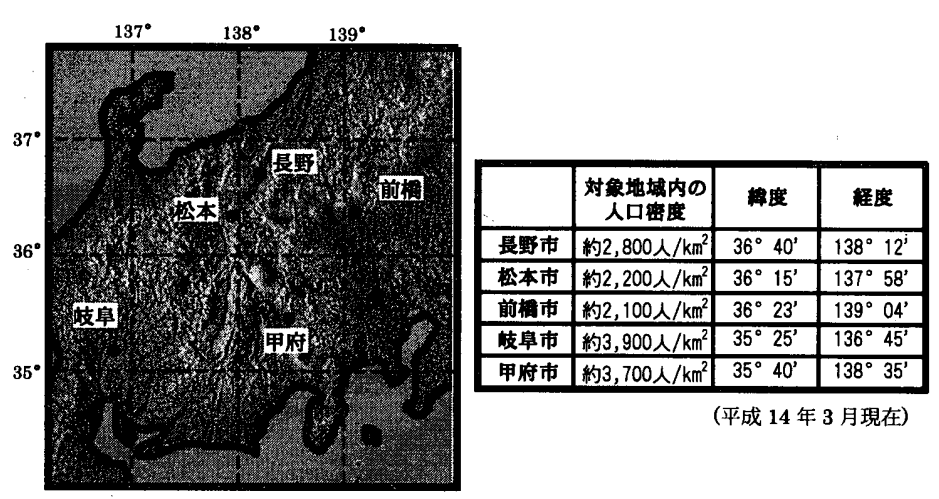

図-1 5 都市の躱要
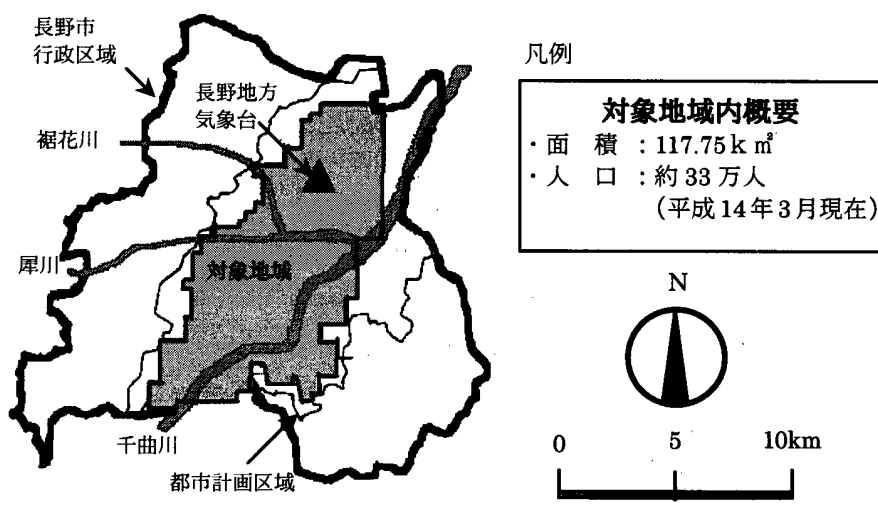

図-2 研究の対象地域（長野市）
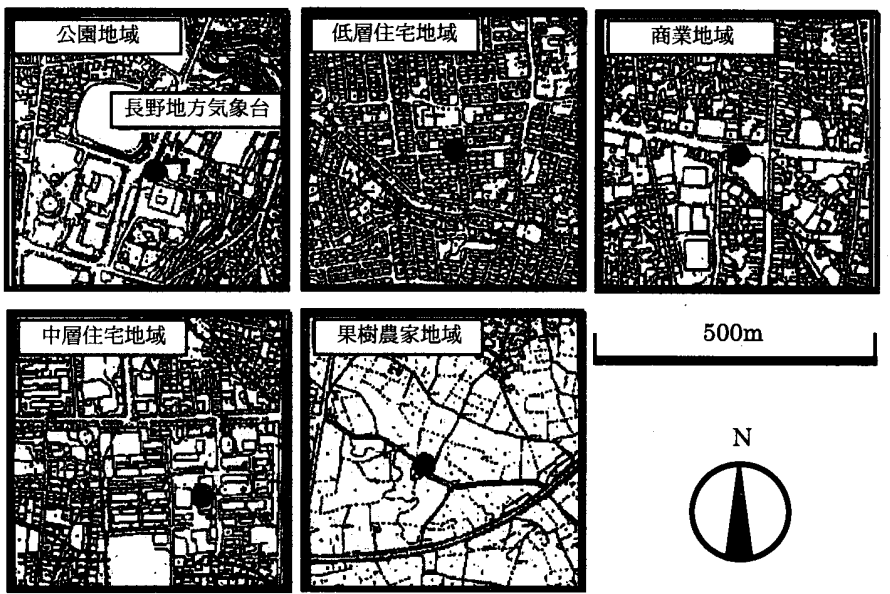

$500 \mathrm{~m}$

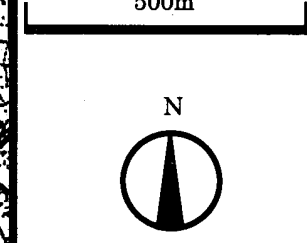

図-3 代表点の概要（長野市）
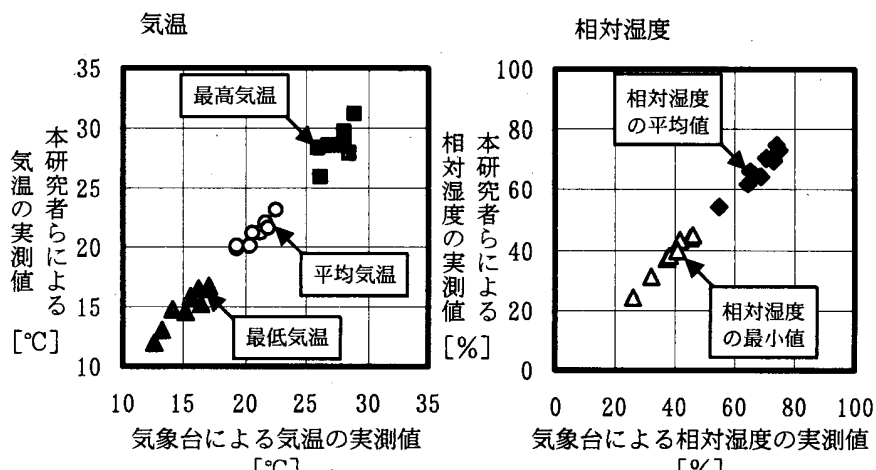

$[\%]$

図－4 露場内における気象台と本研究者らの英測值の比較 

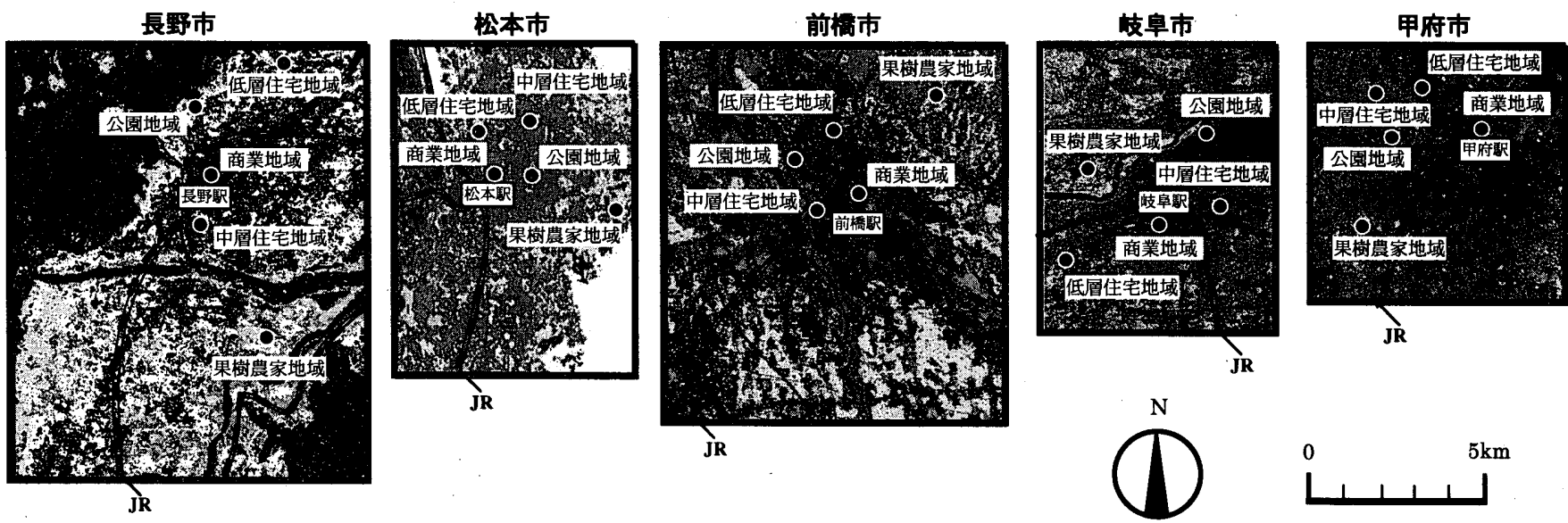

図ー5 リモートセンシングデータを用いた各都市における代表点の逼定

に直射日光が当たらず、建物から $1 \mathrm{~m}$ 以上離れた場所とした。なお、 測定の前に長野地方気象台の露場において、本論文で用いた測定器の 校正を行っている。その方法として、気象台による観測值と本研究者 らの測定器による実測値の比較を行った。その際、各種測定方法を検 討したが、当該測定器を使用した場合は、露場内に測定器をそのまま 設置する方法（但し、センサ一部は日射と雨が当たらない様にプラス チック製の筒に入れる) が、気象台のデータと最も一致する結果とな った。その 10 日間の実測データを図ー4に示す。これより、気温と 相対湿度の誤差は少ないものと判断し、研究を行う上でこの方法を採 用することにした。

また、他の都市についても長野市と同様の方法により測定を行った。 なお、土地利用毎の代表点はリモートセンシングデータを用いて選定

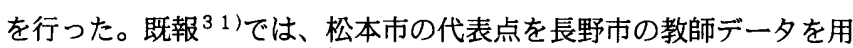
いて選定している。その際、現地調查で確認したところ、解析結果は 妥当であることが明らかになっている。よって、土地利用が同様で対 象地域内に公園地域、商業地域、中層住宅地域、低層住宅地域、果樹 農家地域が存在する場合は、一つの教師デ一夕で他の都市の解析が可 能であると判断し、4 章に示す方法を用いて代表点の選定を行った。

\section{4. リモートセンシングデータによる長野市以外の都市における 土地利用毎の代表点の選定}

\section{1 データの概要}

使用したデータは、1995 年 7 月 28 日と 1999 年 8 月 1 日のランド サット 5 号 TM データで、 $185 \mathrm{~km} \times 185 \mathrm{~km}$ のフルシーンである。これ より対象地域を切り出し、1/25,000 地形図上に設けた GC.P.により、 アフィン変換による幾何補正を行った。なお、補正時の誤差は 0.5 ピクセル以下となっている。

\section{2 教師データの選定}

長野市における図一 3 の土地利用毎の代表点と、既報 1)に示した 検証点を教師データとして、長野市以外の都市における土地利用図 注1)を作成した。なお、土地利用図を作成する際のカテゴリーは、 既報 1)で用いた長野市における、公園地域、低層住宅地域、商業地 域、中層住宅地域、果樹農家地域の 5 つの土地利用に、水田、山林、

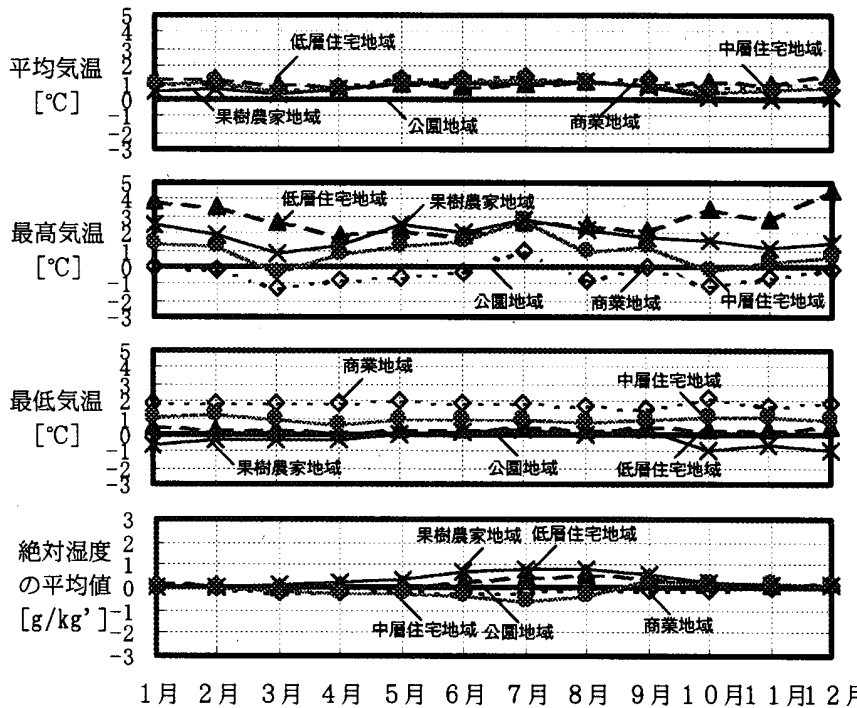

図-6 公㯖地域を基準とした各地域の気温、䎦対湿度（長野）
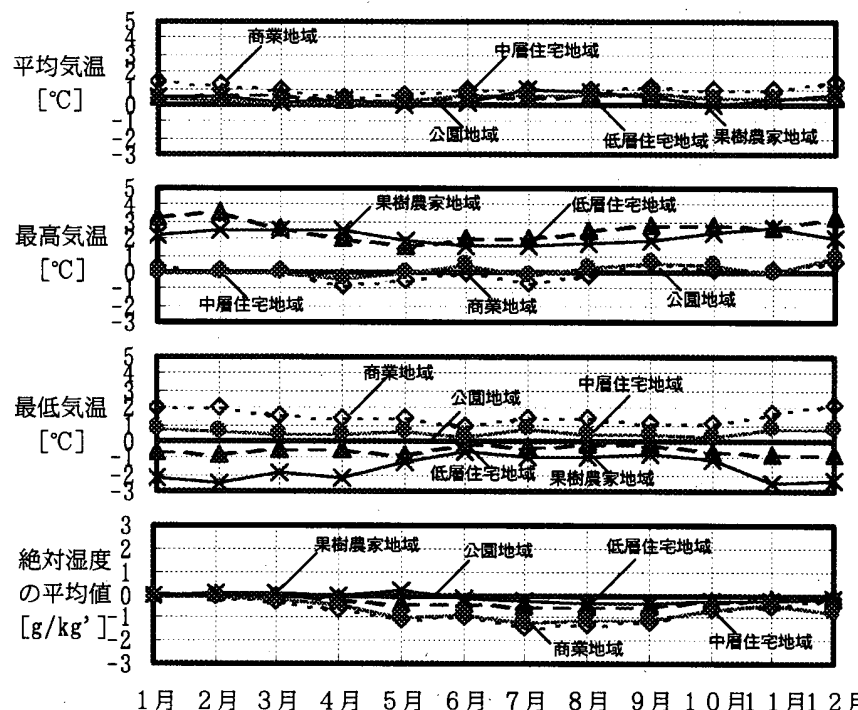

\begin{tabular}{|c|c|}
\hline 凡例 & - \\
\hline & \begin{tabular}{c}
$\cdots \diamond \cdots$ 商業 \\
\hdashline$\quad$ 中層 \\
\hdashline$\quad$ 果樹
\end{tabular} \\
\hline
\end{tabular}


水域を加えた計 8 項目である。

\section{3 土地利用図の作成}

本論文では最尤法を用いて土地利用の分類を行った。具体的にはラ ンドサット 5 号 TM デー夕の計 7 バンドより、分類に使用するバンド 数を4〜7までの全ての組合せ(全64通り)について総当たり計算を行 い、教師データ.との正答率が最も高い分類を採用する事にした。この 結果、各カテゴリーで約 $90 \%$ 以上の正答率が得られたものをそれそ れの地域の土地利用図とした。

\section{4 代表点の選定}

作成したそれぞれの土地利用図より、長野市と同様の代表点である 公園地域、低層住宅地域、商業地域、中層住宅地域、果樹農家地域を 選定し、現地調查を行った上で各都市において代表点を 1 点づつ決定 した。その結果を図ー 5 に示す。それそれの代表点は、既報 1)と 既 報 31)で明らかにした、「20km 四方程度の範囲において土地利用が等 しい場合、気温と相対湿度は信頼度 95\%でほほ一致する」の結果に 従い、何れも代表性があるものと判断した。

\section{5．各都市の通年における代表点の外界気象}

\section{1 通年における各都市の気象状況}

各都市において選定した 5 ヶ所の代表点において、気温、相対湿度 の連続測定を 1996 年から行っている。このうち、本論文では各都市 における 1 年分の実測デー夕 (長野市: 1997 年,松本市: 1999 年, 前橋 市:2000 年, 岐阜市: 2001 年, 甲府市:2001 年）を使用している。

図一 6 10 に各都市における平均気温、最高気温、最低気温、絶 対湿度の平均値をそれぞれ土地利用毎に示す。なお、長野市において は気象台のデータを基準にして他の土地利用との比較を行った ${ }^{1) 。 そ ~}$ の際、長野地方気象台は、図ー3に示す様に公園地域に属する結果と なった。よって、本論文でもその結果との対比を行うため、既報 1) と同様に公園地域を基準にしている。

\section{(1)長野市}

図ー6に長野市の気温と絶対湿度を示す。

平均気温は、公園地域と比べて他の代表点は何れも高く、その差は 年平均で $1.5^{\circ} \mathrm{C}$ とっている。これは、公園地域が丘陵地にあるため 周囲に樹木が多く、直射日光の遮蔽や蒸散作用により低下しているも のと考える。一方、最高気温は地域毎の差が大きく、低層住宅地域や 果樹農家地域は公園地域より高く、商業地域は同様かやや低くなって いる。また、最低気温は低層住宅地域と果樹農家地域は公園地域と同 様であるが、商業地域は公園地域より年平均で $1.9^{\circ} \mathrm{C}$ 高い。この結果、 日較差は商業地域では小さく、低層住宅地域や果樹農家地域では大き い事が明らかになった。商業地域で日中に気温が低いのは、建物によ る日䧔の影響が大きいためと考える。また、夜間はコンクリート等の 熱容量の大きい部材からの放熱により、気温が高くなるものと考える。 絶対湿度は、夏期において土地利用毎の差が大きく、最大で $1.6 \mathrm{~g} / \mathrm{kg}^{\prime}$ の違いが生じている。この時期に最も値が高いのは果樹農 家地域で、低いのは商業地域や中層住宅地域である。果樹農家地域で 絶対湿度が高いのは、当該地域で栽培されているリンゴの木からの蒸 散作用によるものと考える。

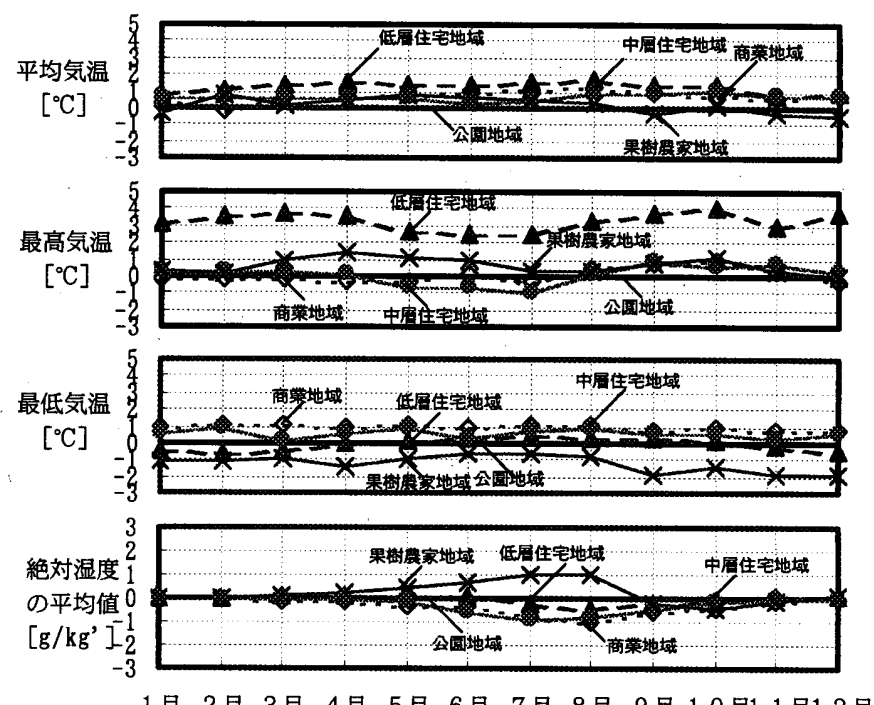

图-8 公圄地域を基準とした各地域の気温、䊉対湿度（前灀）
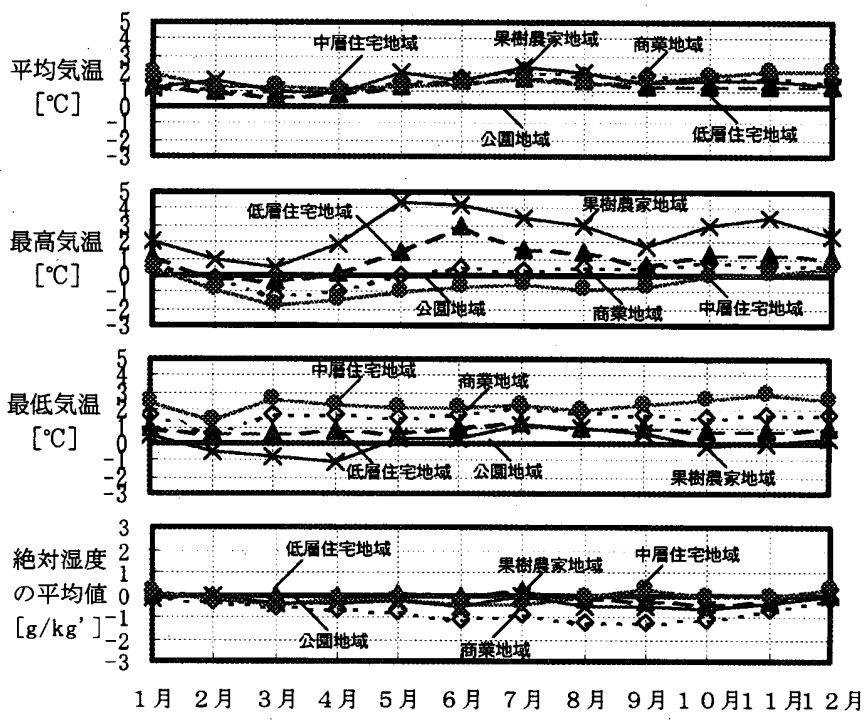

图一9 公園地域を基望とした各地域の気温、解対湿度（岐皁）
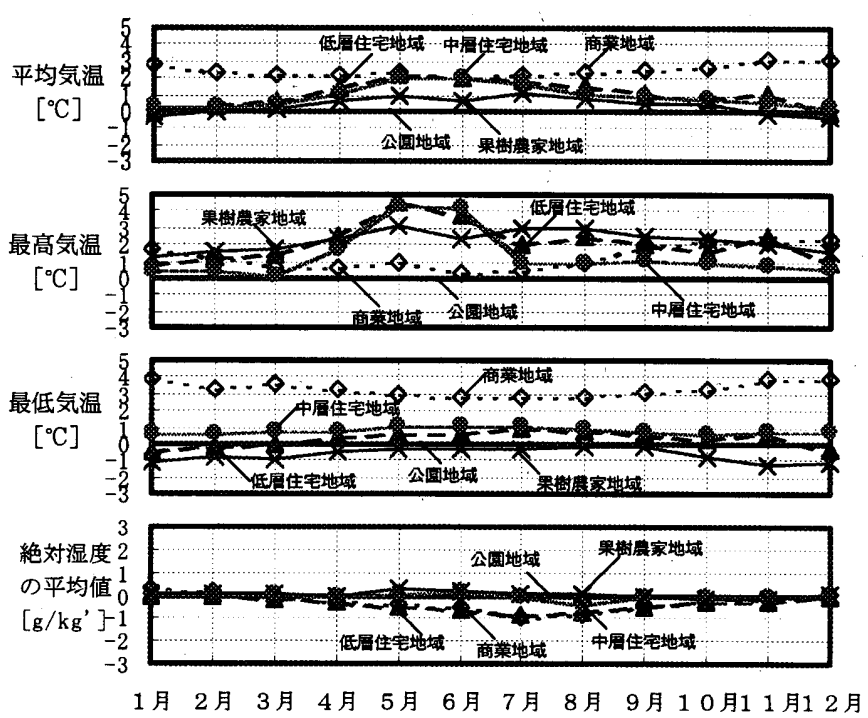

1 月 2 月 3 月 4 月 5 月 6 月 7 月 8 月 9 月 10 月 11 月1 2 月

凡例 公園地域

- - - - 低層住宅地域

图一１0 公團地域を基舫とした

… . . . 商業地域 各地域の気温、緦対湿度（甲府） $\longrightarrow$ 果樹農家地域 


\section{(2)松本市}

図ー7に松本市の気温と絶対湿度を示す。

平均気温は、年間を通じて最も高いのは商業地域で、最も低い公園 地域との差は年平均で $1.1^{\circ} \mathrm{C}$ とっている。一方、最高気温は低層住 宅地域と果樹農家地域が他の地域に比べて高い。最低気温は低層住宅 地域と果樹農家地域が公園地域より低く、逆に商業地域と中層住宅地

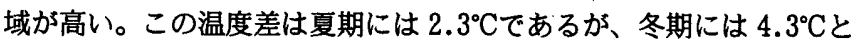
大きくなる。最高気温と最低気温の結果より、日較差は長野市と同様 に商業地域と中層住宅地域では小さく、低層住宅地域と果樹農家地域 では大きい事が明らかになった。

絶対湿度は、公園地域が最も高い。そのピークは長野市と同様に夏 期であり、最小の商業地域に比べて $1.5 \mathrm{~g} / \mathrm{kg}^{\prime}$ 高い值となっている。 (3)前橋市

\section{図ー8に前橋市の気温と絶対湿度を示す。}

平均気温は、公園地域と果樹農家地域が低く、低層住宅地域が高い。 また、地域による気温差は年平均 $1.3^{\circ} \mathrm{C}$ とっている。最高気温は低 層住宅地域が最も高く、公園地域に比べて平均で $3.2^{\circ} \mathrm{C}$ 高い。これに 対して、商業地域と中層住宅地域は公園地域とほほ同様の值となって いる。最低気温は果樹農家地域が公園地域より低く、商業地域と中層 住宅地域が公園地域より高い。しかしながら、土地利用による差は比 較的小さく、年間で平均 $2.2^{\circ} \mathrm{C}$ となっている。

絶対湿度は、 5 月〜8 月にかけて全体で $1.9 \mathrm{~g} / \mathrm{kg}^{\prime}$ の差が生じてお り、果樹農家地域が最も高い值となっている。これは当該地域で栽培 されている桑からの蒸散作用によるものと考える。

\section{(4)岐阜市}

\section{図ー9に岐阜市の気温と絶対湿度を示す。}

長野市と同様に各代表点の平均気温は何れも年間を通じて公園地

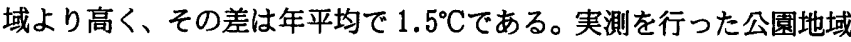
は、金華山等の標高約 300mの山地と荈接しているため周囲に樹木が 多く、その影響で他より値が低いものと考える。最高気温は、低層住 宅地域と果樹農家地域が公園地域より高く、商業地域と中層住宅地域 は公園地域と同様かやや低い。その差は 5 月において最大となり、土 地利用により $5.4^{\circ} \mathrm{C}$ 差が生じている。最低気温は商業地域と中層住 宅地域が高く、公園地域と果樹農家地域が低い傾向である。最高気温 と最低気温の果樹農家地域の值は、何れも変動幅が大きいが、これは この地域で栽培されている柿や枝豆の影響であり、季節により成長や 刈り取り等の土地利用状況が大きく変化するためであると考える。

絶対湿度は公園地域が高い傾向である。これは前記の様に、周囲の 山地と連続して分布する樹木による影響であると考える。年間では夏 期から秋期にかけて土地利用による差が生じており、その差は最大 $2.8 \mathrm{~g} / \mathrm{kg}^{\prime}$ となっている。

\section{(5)甲府市}

図ー10に甲府市の気温と絶対湿度を示す。

甲府市の平均気温は、各代表点の值が 5 都市の中で最も差が生じて

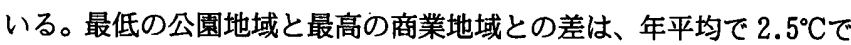
ある。最高気温は地域毎に差があるが、各代表点の値は何れも年間を 通じて公園地域より高い。最低気温は商業地域が最も高く、最も低い

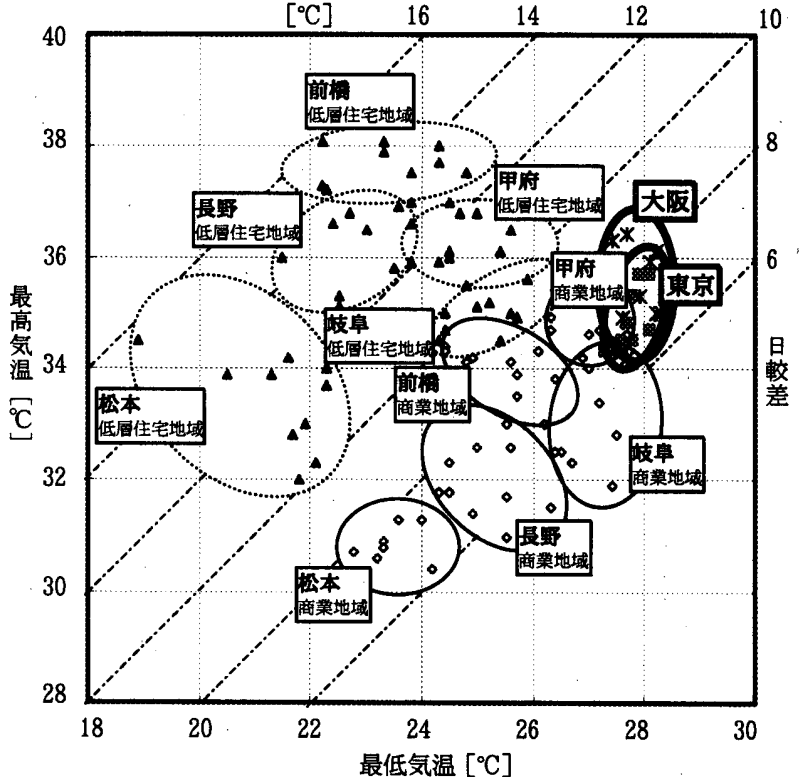

図一 11 最震日における気温の分布

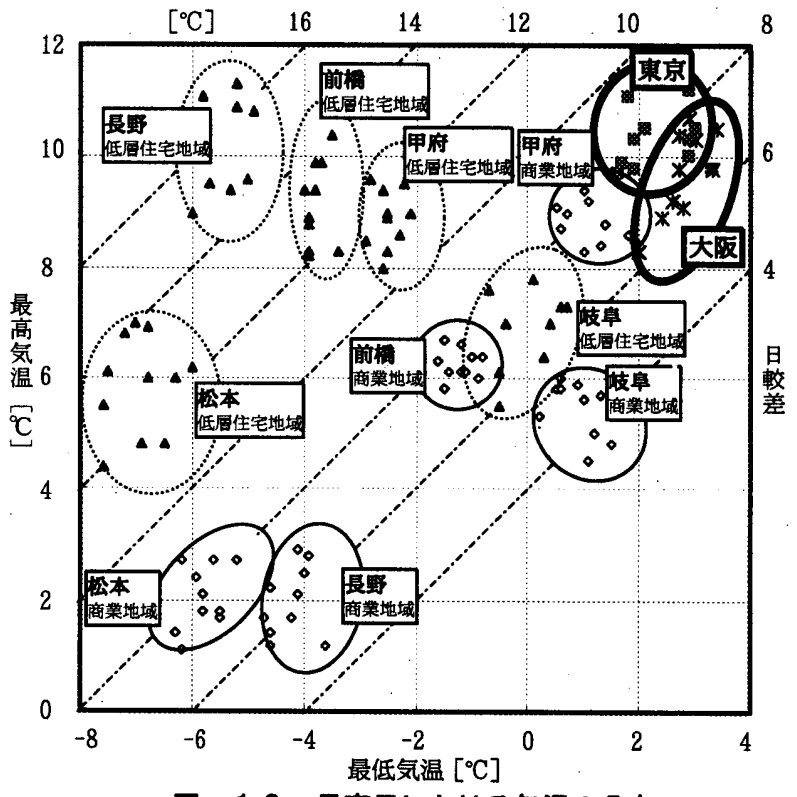

图一-12 取寒日における気温の分布

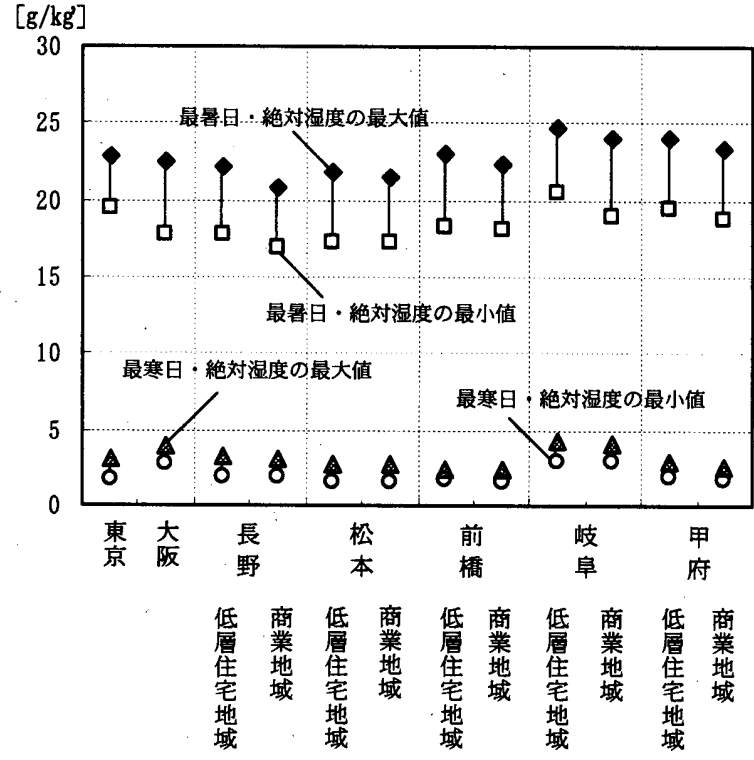

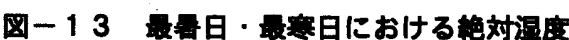


果樹農家地域より最大で $5.0^{\circ} \mathrm{C}$ 高くなる。この温度差も、 5 都市の 中で最大となっている。

絶対湿度は、夏期において全体で $1.0 \mathrm{~g} / \mathrm{kg}^{\prime}$ の差が生じているが、 商業地域と低層住宅地域が他の地域より低い傾向である。

\section{2 各都市の気象の共通点}

前項に示した結果より、5都市の気象についてまとめる。 平均気温は土地利用毎の差は都市により若干異なるが、1.1 2. $5^{\circ} \mathrm{C}$ となっており、公園地域で低い傾向である。これに対して、最高気温 は季節による変動が平均気温に比べて大きい。また、一般に低層住宅 地域と果樹農家地域が高く、商業地域、中層住宅地域、公園地域が低 く、最大で $5.4^{\circ} \mathrm{C}$ 温度差が生じる場合がある。商業地域で日中に気 温が低いのは、建物による日陰の影響が大きいと考える。そのため、 産業や交通等からの廃熱の影響は、今回対象とした都市においては比 較的少ないものと考える。最低気温は、年間における各土地利用によ る違いが最高気温に比べて少ない。商業地域と中層住宅地域が高く、 果樹農家地域、低層住宅地域、公園地域が低い傾向であり、冬期にお いて全体で $5.0^{\circ} \mathrm{C}$ 差が生じる場合がある。

絶対湿度は、夏期において土地利用による差が生じている。特にこ の時期は、果樹農家地域や公園地域で高く、商業地域や中層住宅地域 で值が低い。果樹農家地域で值が高いのは、リンゴなどの各都市にお ける特産品の影響によるものと考える。

以上の事項か、 5 都市における気象の共通点として明らかになった。

\section{6. 内陸の地方都市と大都市の気象の比較}

本章では、5つの土地利用の中から商業地域と低層住宅地域を対象 に、大都市との気象の比較を行う。このうち、 5 都市のデ一夕は前章 の值を使用し、また東京 (東京管区気象台) と大阪 (大阪管区気象台) については 2002 年の気象データ32）を用いている。なお、東京と大 阪の気象観測地点の周辺状況は、共にビルが立ち並ぶ官庁街となって いる。

図ー11に最暑日の最高気温と最低気温を、図ー12 に最寒日の最高 気温と最低気温を、何れも晴天日の 10 日間のデータを用いて示す。

最暑日は、対象にした 5 都市では、何れも商業地域は「最高気温が 低く最低気温が高い」エリアに分布している。これに対して、低層住 宅地域は「最高気温が高く最低気温が低い」エリアとなっている。こ の傾向は、長野市、松本市、前橋市において特に顕著に表れている。 一方、東京と大阪の值はほぼ同様で、最高気温と最低気温が共に高い 状況である。

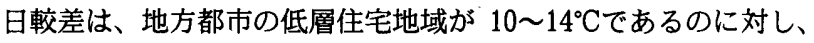

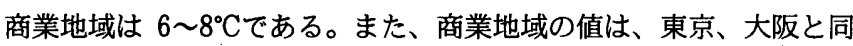
様となっている。

最寒日は、最暑日に比べると都市毎の分布に若干の差が生じている。 最高気温において低層住宅地域と商業地域を比較すると、最も差が生 じているのは長野市で、低層住宅地域が約 $8^{\circ} \mathrm{C}$ 高くなっている。一方、 最低気温では甲府市において最も差が生じており、商業地域が約 $4^{\circ} \mathrm{C}$ 低くなっている。これらの值は、各都市の標高や産業の違いによるも のと考えるが、商業地域において「最高気温が低く最低気温が高い」
こと、また低層住宅地域で「最高気温が高く最低気温が低い」ことは、 最暑日と同様の傾向となっている。

日較差は、岐阜市の值が他とは異なるものの、それ以外の地方都市

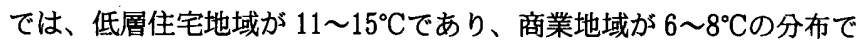
ある。商業地域の値は、最暑日と同様に大都市の値と近似している。

図ー13に最暑日と最寒日の絶対湿度を、気温と同一日を用いて示 す。地方都市の商業地域と低層住宅地域を比較すると、前章で明らか にした様に商業地域の值が低く、特に最暑日においてその傾向が大き い。また、東京、大阪と比べると大きな違いは無いものの、中には值 が高い都市も見られる。これは周辺部の山地による雲の発生や放射冷 却に伴う霧の出現、さらには周囲の植生による影響であると考える。

\section{7.まとめ}

内陸の地方都市である長野市、松本市、前橋市、岐阜市、甲府市を 対象に、各都市の対象地域内において土地利用の異なる代表点をそれ ぞれ選定し、通年における気温と相対湿度の連続測定を行ったところ、 次に示す結果が得られた。

（1）各都市の通年における外界気象の観測を行った結果、平均気温、 最高気温、最低気温、絶対湿度の観点より、5 都市の実態が明らかに なった。このうち、平均気温は公園地域が他の地域より低く、都市に よっては $1.1 〜 2.5^{\circ} \mathrm{C}$ 低くなる事が分かった。この要因は、主に植生 によるものであると考える。

（2）商業地域と低層住宅地域の気温を、東京、大阪と比較した結果、 最暑日と最寒日の最高気温、最低気温、日較差の違いがそれぞれ明ら かになった。特に、5 都市における商業地域の気温は、低層住宅地域 に比べて日中は低く夜間は高いことが分かった。これは、長野市と同 様に他の都市においても、商業地域では日中は建物による日陰の影響 が、また夜間はコンクリート等の熱容量の大きい部材からの放熱が、 それそれ関与しているものと考える。

（3）最暑日と最寒日において商業地域と低層住宅地域の絶対湿度を 比較したところ、何れの都市も商業地域が低い事が明らかになった。 また、東京、大阪と比べると值が高い都市もあるが、これは雲、霧、 植生等の影響によるものと考える。

以上の結果より、内陸の地方都市における土地利用毎の気温と絶対 湿度を中心とした都市気候の実態を明らかにする事ができた。また、 $20 \mathrm{~km}$ 四方の比較的狭い範囲でも、気象の違いがあることが分かった。 ここで得られたデータは、建物の熱負荷シミュレーション計算や有効 なパッシブ手法の検討のための資料として活用可能であると考える。

今後は、気象観測を継続すると共にリモートセンシングを用いた気 象解析を行い、内陸の地方都市の実態をさらに明らかにしていく予定 である。

\section{謝辞}

本研究を実施するにあたり、長野地方気象台、松本測候所、前橋気 象台等の気象観測機関に測定の御協力をいただきました。また、研究 室の多くの学生に測定の補助をしていただきました。ここに記して感 謝の意を表します。 


\section{参考文献}

1)岩井一博，高木直樹 : 長野県北部地域における気象台のデー夕を基準とした 都市気候に関する研究, 日本建筑学会計画系論文集 第 516 号, pp69-77, 1999.2

2)岩井一博，高木直樹，浅野良晴，山下恭弘:地方都市における気象マップの 作成と都市気候の実態に関する研究, 日本建築学会計画系論文集 第 526 号, pp83-90, 1999.12

3)岩井一博, 高木直樹, 山下恭弘 : 長野市におけるパッシブ手法を検討するた めの気象マップの作成に関する研究, 日本建築学会計画系論文集 第 540 号, pp59-66, 2001.2

4)岩井一博, 高木直樹, 山下恭弘 : 土地利用と標高を考虑した気象マップの作 成と気象の実態に関する研究 - 長野市全体を対象にして - , 日本建築学会 計画系論文集 第 558 号, pp63-70, 2002.8

5)首藤治久, 杉山順史, 泉浩光, 岡建雄 : 土地利用形態と気温形成に関する研 究, 日本建築学会計画系論文集 第 479 号, pp 49-56, 1996.1

6)首藤治久, 程青, 横尾昇剛, 岡建雄 : 土地利用形態と気温形成に関する研究 その 2 東海、東北及び関東地域における解析結果と B 值の考察, 日本建築学 会計画系論文集 第 497 号, pp59-66, 1997.7

7)石野久㣂，郡公子, 谷本潤 : 東京首都圈における空調設計用外気温度の分布 特性に関する研究，日本建築学会計画系論文集 第 453 号, pp17-27, 1993.11

8)河野仁，鳴海大典，下田吉之 : 過密都市における気候改善，都市環境のクリ マアトラス

9)武政孝治，小玉祐一郎：AMeDAS デー夕に基づく建築設計用地域気候マッ フの作成(1)気温, 日射量, 暖房度日による地域気候特性の表示, 日本建築学 会大会学術講演梗概集 環境工学, pp1017-1018，1992.8

10)小玉祐一郎，武政孝治 : AMeDAS テー夕に基づく建築設計用地域気候マッ プの作成(2)PSP(パッシブ地域係数)による地域気候特性の表示, 日本建第 学会大会学術講演梗概集 環境工学, pp1019-1020, 1992.8

11)西川邦彦, 斎藤郁雄, 石原修: 自然エネルギーの活用のための気象テータ の整備と気候マップの作成，日本建築学会計画系論文集 第 509 号,pp15-20, 1998.7

12)無漏田芳信, 小村治, 小林定教, 地濃茂雄, 酒井要 : 人口都市化期におけ る日本各地の温湿度変化特性, 日本建築学会計画系論文集 第 521 号, pp189-194, 1993.11

13)片山忠久, 石田昭夫, 西田勝, 堤純一郎, 森川明夫, 橋田光明 : 水面を有 する市街地の熱環境に関する調查研究，日本建築学会計画系論文集 第 372 号, pp21-29, 1987.2

14)村川三郎，関根毅，成田健一，西名大作，千田勝也 : 都市内河川が周辺の 温熱環境に及ぼす効果に関する研究 (続報) - 水平および鉛直的影響範囲の 検討 - ， 日本建築学会計画系論文集 第 415 号, pp9-19, 1990.9

15)成田健一, 植村明子, 三坂育正 : 都市気候に及ぼす河川水の熱的影響に関 する実測研究 - 隅田川における熱収支と周辺影響の検討 - , 日本建築学会 計画系論文集 第 545 号, pp71-78，2001.7

16)向井愛，堀越哲美 : 名古屋市中川運河における海風逼上が体感気候に及ぼ す影響，日本建築学会計画系論文集 第 553 号, pp37-41，2002.3

17)村上周三, 持田灯, Sangjin KIM, 大岡龍三 : 関東地方における土地利用 状況の変化と流れ場・温度場の関係 - Mellor-Yamada 型の都市気候モデル による局地気象解析 -, 日本建築学会計画系論文集 第 491 号, pp31-39, 1997.1

18)ヴタンカ, 足永靖信, 浅枝隆 : 都市大気境界層の乱流モデリングー都市建 築計画における都市気候予測システムの開発 その 1 -, 日本建築学会計画 系論文集 第 536 号, pp95-99, 2000.10

19）竹林英樹，森山正和，村上周三，大岡龍三，持田灯，芝池英樹，吉田伸治 : 数值モデルによる計算結果と観測テータを併用した都市スケールの気候解 析, 日本建築学会計画系論文集 第 556 号, pp63-68, 2002.6

20)吉田治典 : 気象データのモテル化と環境設計, 日本建築学会環境工学委貝 会，熱環境小委員会第 27 回熱シンポジゥム，pp49-58，1997
21)渡辺浩文, 依田浩敏, 尾島俊雄 : リモートセンシングデータと数值情報利 用による広域都市の地表面温度分布図の作成に関する研究，日本建築学会計 画系論文集 第 443 号, pp21-29, 1993.1

22)梅干野晃, 浦野良美, 小田健一，浜口典茂 : 住宅地における夏季・冬季熱 環境実態および土地被覆率との関係 リモートセンシングによる住宅地の熱 環境解析( III), 日本建築学会計画系論文集 第 331 号, pp 38-44, 1983.9

23)中村泰人，平岡久司，西村浩一：市街地空間における表面の温度および熱 流性状に関する実験的研究,日本建築学会計画系論文集 第 364 号, pp 57-65, 1986.6

24)尾岛俊雄，岡建雄 : 市街地空間の熱的環境に関する研究 その 1 熱拡散に 関する基礎理論解析， 日本建築学会計画系論文集 第 240 号, pp101-111, 1976.2

25)谷本濯，石野久彌 : 細密数值情報を用いた東京首都圈における空調設計用 外気温度分布特性に関する研究, 日本建築学会計画系論文集 第 483 号, pp27-32, 1996.5

26) 森山正和, 鈴木和弘, 宮崎ひろ志 : ランドサットテータを用いた夏季の広 域的温熱環境評価に関する研究, 日本建築学会計画系論文集 第 482 号, pp27-32, 1996.5

27)持田灯, 村上周三, Sangjin KIM, 近藤裕照, 島田照男, 玄地裕, 吉田伸 治：ヒートアイランド現象の解析とその対策技術の総合的評価のための Sof tware Platform の開発と風環境の解析事例, 第 16 回風工学シンボジウム 論文集，pp137-142，2000

28)西岡真稔，松尾陽 : 都市キャノピーにおける建築の放散熱とその影響 一そ の 1 建築の熱放散に関する伝熱モテルー，日本建築学会計画系論文集 第 508 号, pp29-34, 1998.6

29)平岡久司 : 樹木の熱・水分・二酸化炭素収支のモテル化に関する考察, 日 本建築学会計画系論文集 第 546 号, pp53-60,2001.8

30)杉山寛克, 持田灯, 村上周三，尾島俊雄 : 沿岸部における都市圏の拡大か ヒートアイランドの形成に及ぼす影響に関する解析，日本建築学会計画系論 文集 第 492 号, pp83-90, 1997.2

31)高木直樹, 岩井一博, 山下恭弘 : リモートセンシングデータと実測データ を用いた地方都市における気象マップの作成に関する研究, 日本りモートセ ンシング学会誌, Vol.20 No.4,pp67-79，2000 年

32 )気象仃編: 気象庁月報, (財)気象業務支援センター, 2002

注 1)

本論文ではリモートセンシングデータを使用し、代表点を教師データとした 土地被覆分類を行った。そのため、教師データにより分類された地域はそれぞ れ同一の土地被覆になるものと考える。

これらの地域について現地調査を行ったところ、教師データの土地利用と同 じ土地利用の場所が多く見られた。例えば、商業地域はコンクリート系の建物 やアスファルト道路が主体で、土や植生などの敷地の占める割合が少ない。中 居住宅地域は、商業地域と同様にコンクリート系の建物やアスファルト道路が 多いが、その中に土や植生が湿在している。低層住宅地域は軗地が主であり、 そこに瓦やトタン咠きの屋根やアスファルト道路が分布している。果樹農家地 域はリンゴ、ブドウ、桑、枝豆畑等が主体で、所々に建物が集合している。公 園地域は土や植生がほとんどを占め、緑被率が高い地域である。

なお、土地被覆状況と土地利用が明らかに異なる地点のデータについては解 析対象外とした。

これらの地域の具体的な建物、道路、敷地の各面積率については、商業地域、 低層住宅地域、果樹農家地域は既報 1)の表一2に示す値に準扴している。また、 中層住宅地域は表中の商業地域と低層住宅地域の中間値で、公園地域は土也植 生による敷地率が $60 \%$ 以上占める地域となっている。

以上の事項に基づき、土地被覆分類のデータを土地利用分類のデータとして 使用し、これによって分類した図を土地利用図と呼称した。 